Article

\title{
Assessment of Diversity Outcomes in American Medical School Admissions: Applying the Grutter Legitimacy Principles
}

\author{
Aaron Baugh ${ }^{1}$ and Reginald F. Baugh ${ }^{2, *}$ \\ 1 Department of Medicine, University of California, San Francisco, CA 94143, USA; aaron.baugh@ucsf.edu \\ 2 Department of Surgery, College of Medicine, University of Toledo, Toledo, OH 43614, USA \\ * Correspondence: reginald.baugh@utoledo.edu; Tel.: +1-419-383-6834
}

Received: 22 April 2020; Accepted: 19 June 2020; Published: 26 June 2020

check for updates

\begin{abstract}
In the last 30 years, except for female participation, the enrollment of Latinx, African Americans, Native Americans, Alaskan natives, and disadvantaged students in medical school has been constant; however, increasing enrollment of these minority populations is feasible, if admissions committees make two changes in approach. First, the traditional belief that matriculation merit is a linear function of past academic performance must be rejected. Second, once the threshold needed to complete medical school in four years and to pass licensing examinations at the first attempt has been met, all candidates are equally qualified, and matriculation decisions must be based, in part, on societal interests. In Grutter vs. Bollinger, the United States Supreme Court determined that graduate admission committees can and should consider societal interests. Each admission decision represents a substantial government investment in each student, as the Medicare Act directly subsidizes much of the cost of medical education. As Grutter explained, there is a societal interest in the public having confidence in, and access to, the medical school training that will prepare tomorrow's medical, professional, and political leaders. Our analysis suggests that medical school admissions are biased towards academic achievement in matriculants, beyond acceptable thresholds for graduation and licensure. We believe medical schools must shift their admissions strategies and consider noncognitive factors in all candidates as determinative once minimum acceptable academic standards have been met.
\end{abstract}

Keywords: Grutter vs. Bollinger; undergraduate grade-point average (GPA); Medical College Admission Test (MCAT) score; widening access; social justice; diversity and inclusion; medical school admissions; legitimacy principles; non-cognitive

\section{Introduction}

Medical student selection shapes the quality and character of the medical profession. The process therefore has an outsized importance in the public perception of the healthcare system's legitimacy. Recognizing this dynamic, many nations have expressed an intention to widen the participation of underrepresented groups among the ranks of physicians. Despite a variety of underlying strategies, legal regimes, and social conditions, success has been scant. We propose that this is due to a conceptual paradigm that misconceives trainee quality and sees it in opposition to diversity. Using the United States as a case study, we briefly review the development of this ideology and then examine the underlying evidence for past academic performance as a measure of medical school performance. Finally, we offer a new framework for understanding priorities in trainee selection. 


\section{Background}

While open, active opposition against widening access is unusual, opposition lies in institutional beliefs and norms regarding diverse students lacking the resources, incentive, and, cumulatively, the academic preparation to be successful [1]. Such beliefs have a long legacy within American medical education. The Flexner report was transformative, emphasizing academic standards and basic science curricular elements to professionalize the discipline. In addition to review of applicants' prior academic performance, it would also spur the widespread adoption of standardized entrance exams. While studies of medical student attrition better supported a threshold effect than a linear relationship between past academic achievement and graduation as early as the 1960s [2], medical schools have tended to prefer selecting among the highest scorers [1,3]. The report also acknowledged the importance of minority representation in the medical field. However, as Flexner's critics have noted, and the report itself conceded, adopting its whole body of recommendations would have the perverse effect of reducing participation from marginalized groups unless there were significant efforts to address underlying inequities in the social structure [4]. Both points were largely ignored, and in consequence the majority of medical schools supporting female and African American enrollment closed. In consequence, sharp improvements in the quality of medical care coincided with steep declines in medical training for females, minorities, and individuals from low-income households.

This trend would not be challenged for several decades, until the advent of the Civil Rights movement in the 1960s. While programs were initially designed to correct historic injustices, emergent evidence later highlighted the intrinsic benefits of diverse learning environments [5]. Regardless, these efforts have proved a significant flashpoint for public controversy. A UK initiative to broaden access to higher education was denounced as the work of "Trotskyists"; senior politicians tellingly insisted, "Academic merit and potential should be the only factors in deciding university admissions" [6,7]. Though such policies are now widespread in the UK, actual improvement in recruitment has proved difficult [1]. In Canada, where medical schools have attempted to address the problem with a similar policy program, the perceived prestige of higher grade-point average (GPA) and Medical College Admission Test (MCAT) scores is noted as a major barrier to effective implementation [8,9]. A study of Danish medical school admissions found that applicants from diverse backgrounds performed equally as well as more traditional students on attributes-based admissions procedures, but significantly worse when cognitive tests were the primary determinant [10]. This rhetoric is borrowed even where it does not obviously apply. In Japan, a scandal to reduce female participation in medical school chose to do so by manipulating entrance exam scores [11]. That the conspirators cloaked their actions in the guise of concerns around academic excellence rather than many other possible points of intervention speaks to the power of this narrative.

Alternative views asserting the value of diversity have at best co-existed with this more traditional formulation of excellence as academic linearity. More precisely, this seems to evidence a trust gap between declared policies around diversity, equity, and inclusion (DEI) versus the perception of both administrators and the general public. Public perception of DEI efforts has been relatively less explored in the medical literature. Doing so may offer important insights. Medical education is a subsidized endeavor in most countries, thereby representing an expression of governmental policy. According to the systems theory of political science, in liberal democracies such systems are dependent on public trust [12]. In policy-making, trust has been shown to reduce transaction costs [13]. High trust conditions increase compliance with new processes and regulations because participants accept them as both credible and sincere, thereby improving efficacy [14]. Such a dynamic led administrators at the University of Michigan to employ innovative tactics like the $1 \%$ solution to achieve significant improvements in student and faculty diversity during the 1980s. [15,16]. The converse of this principle is readily observed in the hidden curriculum of medical education: faculty members without confidence in DEI initiatives undermine them through non-compliance [17]. These dynamics become even more apparent when considering the case of the United States. 
In comparison to the contretemps of the international experience, the American iteration magnifies the issues in ways that lend themselves to study. Its DEI efforts in higher education have been extensively litigated in a series of Supreme Court rulings in 1978, 2006, and 2016 [18-22]. This forced all parties to articulate their reasoning at length. Each plaintiff centered their claim on the notion that because they had better prior academic performance than some accepted students, they were necessarily more meritorious. The most important of these cases in shaping the general population's attitude towards the role of diversity in medical education was Bakke vs. University of California [18]. The Supreme Court's decision set the tone for subsequent debate around the topic, stressing fairness for the individual applicant and rhetorically positioning academic merit as a force at odds with the desire for diversity. Most crucially, it accepted the premise that the candidate's prior academic performance rendered him a more meritorious candidate for admission.

Currently, medical school admission decision-making focuses almost exclusively on individual justice. The admissions committee's work primarily consists of determining the applicant's academic merit and personal qualifications. The goal is to be objective, and as fair as possible to the individual. Undergraduate academic transcripts are examined, Medical College Admission Test scores considered, and letters of recommendation reviewed. Reinforced by habit and litigation alike, the belief that matriculation "worthiness" is primarily a linear function of past academic performance prevails [3]. By this logic, the candidate with the higher grade point average (GPA) and/or MCAT score is better qualified, and, hence, more meritorious. Indeed, most graduate admissions litigation is rooted in a claim that the qualification determination was faulty. The matriculating institution's interest in considering race or other non-cognitive factors has been insufficient justification for any significant deviation from strict academic linearity $[18,19]$.

In a 2003 decision, Grutter vs. Bollinger, [21] the Supreme Court evaluated the University of Michigan Law School's admissions policies. They determined a broader, more holistic admission analysis was warranted, beyond merely academic achievement. The legitimacy principles articulated in the Grutter [21] decision provide guidance for achieving those goals in medical school admissions and enhancing the learning environment.

The Grutter Court stated, "In order to cultivate a set of leaders with legitimacy in the eyes of the citizenry, it is necessary that the path to leadership be visibly open to talented and qualified individuals of every race and ethnicity. All members of our heterogeneous society must have confidence in the openness and integrity of the educational institutions that provide this training. As we have recognized, law schools "cannot be effective in isolation from the individuals and institutions with which the law interacts." Access to legal education (and thus the legal profession) must be inclusive of talented cultures and qualified individuals of every race and ethnicity, so that all members of our heterogeneous society may participate in the educational institutions that provide the training and education necessary to succeed in America." (Internal citations omitted) [21].

The Grutter decision [19] clearly articulated the need for a critical mass of diverse students [22] defined not by "checkbox diversity" [23] or percentages, but by the benefits that a diverse student body brings. Benefits accrue not from the aggregate group of diverse members, but by the unique contributions of each student to the educational milieu. In a non-hostile social environment that lacks a critical mass, diverse members are less likely to express their unique ideas or perspectives [24-26]. In the hostile environment that characterizes most American medical schools [27], diverse students are even less likely to manifest their unique contributions. The parabolic relationship of critical mass means the limited number of racial/ethnic minorities at most schools constrains the educational benefits to all learners [28].

Since Grutter vs. Bollinger, significant shifts in medical school admission strategies have emerged. New assessment techniques include holistic reviews [29,30], multiple mini interviews (MMI) [31], and greater emphasis on humanity and social science preparation $[32,33]$. The hope that each shift in program emphasis would increase diversity enrollment has not been achieved. There is no evidence that the changes have made any significant difference. Admissions committees consistently believe 
that matriculation merit is linearly related to past academic performance; a belief that is not empirically supported when applied beyond a minimum threshold for medical school and licensure success [3]. The use of the mean MCAT scores and undergraduate GPAs of accepted students as a marker of medical school quality by periodicals like U.S. News $\mathcal{E}$ World Report is an abuse that further encourages this trend. The resulting rankings raise public and medical school administration expectations that admissions committees select for the highest possible score for every incoming class.

The myth of academic linearity has been a substantial barrier to achieving medical school diversity, but it need not remain so. The goal of training "talented and qualified individuals" from "every race and diversity" as described by Grutter vs. Bollinger [21] can be achieved. The candidate pool with the qualifications to complete medical school is much more diverse than traditional matriculated classes would suggest. Diverse candidates who can complete medical school and pass their licensing examination on the first attempt are just as "qualified" as any other potential enrollee on those criteria. Medical school admissions committees must broaden their admissions criteria to make this judgment if they are to admit diverse student bodies.

\section{Materials and Methods}

This paper evaluates diversity outcomes produced by American medical school admission practices. Diversity will be defined as women, racial/ethnic minorities, and the economically disadvantaged. The disadvantaged refers to those matriculants whose combined parental income was less than $\$ 26,000$, a rough approximation of the federal poverty line [34]. The working class shall be defined by the second and third quintiles of parental income (about $\$ 26,000-70,000$ ). Combining the disadvantaged and working-class population represents two-thirds of all Americans, about $75 \%$ of African American/Blacks, 67\% of Latinx, and 40\% of Whites [35]. Racial/ethnic minorities refer to African American/Black, Latinx, Pacific Islanders, and Native Americans and Alaskan natives.

The analysis will only seek to answer the question of whether medical school admission is "visibly open" [21] to students who are academically qualified based only on their GPA and MCAT scores. The MCAT and GPA criteria utilized will be limited to that associated with the successful completion of medical school within four years without academic difficulty. In the United States, the GPA is a quantitative translation of its widely-used letter grading system, ranked from $0-4$. The highest performance, an " $\mathrm{A}$ " grade would receive a 4.0, while every letter grade lower receives one point less. Sponsored in various forms by the American Association of Medical Colleges since the 1940s, the MCAT is a multi-choice standardized test divided into several sections deemed important for medical training. Its use as an admission aptitude test is near universal within the country. The analysis is limited to these two factors because they figure prominently in the Supreme Court medical school admissions cases [18-22], and they are universally significant in admission decision-making regarding granting both interviews and acceptance [36,37]. Our primary analysis will retrospectively analyze the longitudinal demographics of American medical school matriculants to understand whether the above-defined diverse applicants have meaningfully increased in proportion. Medical school matriculation is used as a proxy for graduation due to historically high graduation rates. Our secondary analysis will utilize publicly available outcomes data to investigate whether medical school performance is best modeled as a linear function of prior academic performance. The primary predictors in this analysis will be undergraduate GPA and MCAT score. The primary outcomes will be successful advancement in medical school and graduation rate. Successful advancement shall be defined as the completion of Year 2 in two years and completion of Step 1 USMLE on the first attempt, since the vast majority of students meeting these criteria go on to graduate on time. Comprehensive longitudinal data on medical school graduation rates for MD students remained stable from 1993-1994 through 2012-2013, varying from $82-84 \%$ (96\% at six years) for all matriculants [38]. Hence, expected graduation rates above $85 \%$ in two years are deemed to have met academic standards in our analysis. Rather than new statistical analysis, we will focus on synthesizing existing reports and data. 
Non-cognitive factors will not be considered. They have no uniformly agreed-upon definition [18] and have not been a feature of affirmative action litigation. The absence of any American data where student selection was independent of both GPA and MCAT scores necessitates that we assume the non-cognitive factors are equal.

American medical school graduates must pass the (USMLE) licensing examinations to be eligible for state licensure. Unlike American law schools, typically, there are tight linkages between eligibility for graduation and successful completion of USMLE requirements [39]. In this regard, all medical school graduates independent of their schools' ranking or educational mission are the same: fully eligible to become a practicing physician. In our analysis, for every school, we postulate there is a threshold for undergraduate GPA and MCAT score above which incoming students must achieve. This standard may differ between schools and reflects their unique collective educational environment (applicant pool, students, instructional method, faculty, curriculum, and mission). The "Acceptable Threshold" for admissions is defined as the minimal clinically meaningful difference between combinations of undergraduate GPAs and MCAT scores (nationally) resulting in expected medical school graduation within four years. It assumes a medical school class size of 175 and a success rate equal to the national rate. Class sizes less than 175 would have different Acceptable Thresholds.

\section{Results}

\subsection{Outcomes: Racial/Ethnic Minorities}

In the past 35 years, racial/ethnic representation has actually decreased in medical school matriculants relative to the racial/ethnic distribution of the US population. [40]. However, the Department of Education statistics demonstrate significant increases in racial/ethnic minorities' college graduation over the last 30 years [41] and population growth in those age segments in the US population [40]. Between 2000 and 2014, the number of African American/Black applicants to medical school increased by over 30\%, with no corresponding increase in the number of African American/Black matriculants [42]. Studies have shown a $42 \%$ increase in the number of racial/ethnic minorities earning PhD science or engineering degrees between 2008 and 2016 [43], an increase in the number of medical school applications [40], and an almost a $27 \%$ increase in available medical school seats over the past thirty years.

\subsection{Outcomes: Economically Disadvantaged}

The wealthy dominate medical school enrollment. The proportion of students from the top quintile ( $20 \%$ of the population) of income exceeds the number from the bottom four quintiles combined $(80 \%)$. Further, between 2007 and 2017 between $24 \%$ and 33\% of medical students were from household incomes from the top 5\% of incomes in America. This percentage exceeded the combined percentage of matriculants from the bottom $60 \%$ of income brackets (the working class and the disadvantaged combined) [44]. Because medical school classes are skewed toward students from wealthy households and wealthier students go on to serve fewer patients from disadvantaged, rural, racial/ethnic, and other underserved communities, physician shortages in these areas are worsened and perpetuated [45-49].

Women and racial/ethnic groups tend to prioritize values of altruism, empathy, benevolence, and social interdependence to a higher degree than do men and/or non-Hispanic Whites [50,51]. Multicultural individuals develop cross-cultural fluency that allows them to communicate and be effective between cultures [52,53], an important competency in America. Recent reviews find the disadvantaged display increased attention to others, exhibit greater sensitivity to others' welfare, have higher empathy [54], emphasize self-transcendent values [54,55], encourage social responsiveness and social connectivity [56], may also possess greater cultural understanding [57], and are more likely to engage in other-beneficial prosocial behaviors compared to individuals of higher social class [58].

It is important to note social class is likely to be as powerful as that of race/ethnicity as a future predictor of behavior, and there are likely to be significant interactions between class 
and race/ethnicity [59]. Racial/ethnic minorities and the disadvantaged tend to practice in medically underserved areas $[48,49]$. Though they are a small fraction of the workforce, physicians of color are responsible for delivering care to the majority of patients of color [60]. They have historically expressed a desire to practice in medically underserved areas at $50-100 \%$ greater frequency than most medical students [61]. Practice patterns reflect their greater desire to practice in underserved communities [46,47,49,60,62-64]. Further, despite rising household incomes among racial/ethnic minorities in recent years, a greater percentage of these students have continued to express an interest to practice in a medically underserved area [46].

\subsection{Outcomes: Women}

Following the passage of Title IX legislation in 1972, women's access to higher education increased dramatically, and medical school enrollment increased similarly. Over the next 45 years, the percentage of women enrolling in medical school went from less than $20 \%$ to over $50 \%$, a rate proportionally representative of the population [65]. Numerical parity should not be confused with social equality. Undervaluation of the scholarly contributions and the roles that racial/ethnic minorities, women and other stigmatized groups play individually and collectively occurs [66], leaving the field of medicine diminished $[67,68]$. Gender inequalities in salaries and advancement contribute to the attrition of women from academic roles [69-71]. These factors explain, in part, why gender parity has not translated into a greater representation of women among medical school faculty or leadership roles more broadly. Efforts to address the implicit biases within medicine's culture will be necessary to achieve true gender equality [72-74].

Interestingly, although the number of white males admitted to medical school decreased by over $40 \%$, major civil-rights litigation has not been connected to the dramatic increase in female enrollment. Likewise, there have been no calls for financial means-testing of female beneficiaries of affirmative action programs, as has been seen with racial/ethnic minorities. The boost in female admissions has largely replicated the racial/ethnic disparities previously discussed [74].

\subsection{Acceptable Threshold Students}

Historically, despite conventional wisdom saying academic performance at all levels correlates linearly with success, ample evidence exists for medical school's ability to use non-cognitive factors to identify potentially successful matriculants above an acceptable threshold. Historically, $80 \%$ of the students who entered medical school with total MCAT scores between 24 and 26 (about a 495 on the MCAT 2015; less than the 50th percentile) graduated within four years, and 91 percent graduated within five years, a result not dissimilar from the medical school graduation rate. Similar success rates on USMLE Step exams were achieved, and few of these medical students left medical school for academic reasons [75]. Students with GPAs higher than 3.4 [76] and/or composite MCAT scores greater than 30 were just as likely to complete medical school [76] as those with higher scores [77]. This range of GPAs and MCAT scores is far more diverse than traditional matriculants, incorporating many more of the disadvantaged, working-class, and racial/ethnic minorities [78-80]. Historically, when data from 14,275 students were followed during their academic career, academic linearity did not characterize those who experienced academic difficulty (i.e., the stated reason for leave of absence, change in graduation date, withdrawal, or dismissal was academic difficulty) (Figure 1) [77,81].

Merit, as quantified by incoming undergraduate GPA or MCAT scores, has never been shown to have a strong correlation with success in clinical medicine or biomedical research [3,82-84]. Physician clinical assessments and practice beyond resident training, their contributions to their community, or furthering the institutional mission to "service" are independent of undergraduate GPA or MCAT scores [82]. This is not unexpected. Cognitive markers can only reliably be predictive of future competence and performance beyond residency for a very limited time or not at all [85-87]. Further, the predictive value of MCAT scores varies widely between schools depending on available support services (personal, financial, learning, disability, and academic counseling) and school mission, 
suggesting that factors other than cognitive ability are important and that schools can by providing greater support services admit a wider range of students [81]. Innovative curriculums and support services can enhance a student's clinical abilities beyond what their MCAT score would predict [88].

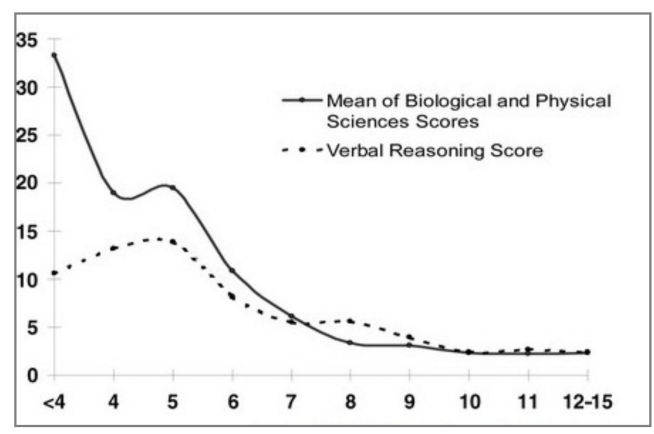

Figure 1. Proportion of students with academic difficulty. This figure illustrates that the proportion of students experiencing academic difficulty decreases as Medical College Admission Test (MCAT) scores increases in general (with exceptions), but unmistakably not in a linear fashion. Beyond the midrange of scores (8-9), the proportion of students experiencing academic difficulty is relatively stable (<5\%). Data from all 14,275 US students with complete data (from a total of 16,289 matriculants) who matriculated in 1992. Figure 3f from Julian ER. Validity of the Medical College Admission Test for Predicting Medical School Performance. Acad Med 2005;80(10):910-917. Used with permission from Wolters Kluwer.

The MCAT 2015 covers different content, but by design should produce similar results [89]. Concordant with the 2019 Association of American Medical Colleges (AAMC) advice, small differences in MCAT scores are not significant. The most recent review of medical student progression (Figures 2 and 3) has demonstrated that above a threshold, academic progression was similarly independent of GPA and MCAT scores [78]. Nationally, the MCAT 2015 Academic Threshold appears to be about 503 (Figure 3). GPAs show no discernible threshold (Figure 2). Differences in the sizes of the applicant pools, curriculums, and support services preclude direct comparisons with any specific medical school, but such calculations are easily performed for any school. Medical schools have demonstrated that they can identify candidates from a broad spectrum of GPAs and MCAT scores that can be successful. Although statistical differences can be shown in the national pool [78], it is unlikely that such differences would be relevant in a typical medical school admission pool. The unproven relationship between the entry parameters (GPA and MCAT scores) and subsequent practice beyond residency make the statistical differences clinically meaningless. Moreover, social and societal accountabilities and responsibilities make the differences of a few percentage points in relation to any individual irrelevant.

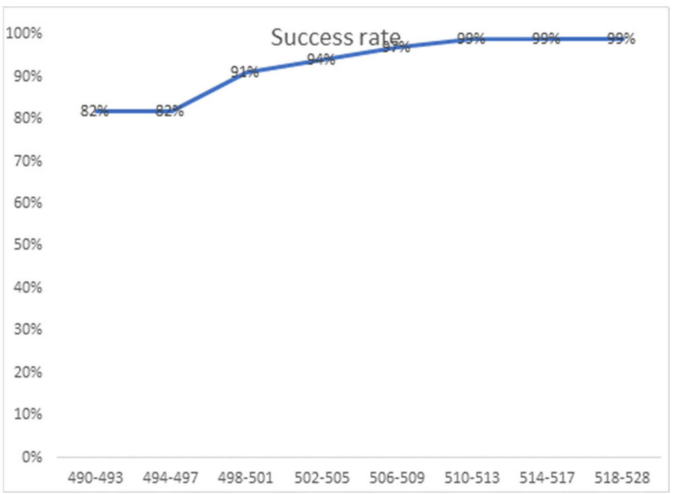

Figure 2. MCAT total score. Percent of successful progression through Year 2. This figure illustrates that Percentage of students admitted in 2016 who progressed to Year 2 on time, by MCAT 2015 Total Score range. 


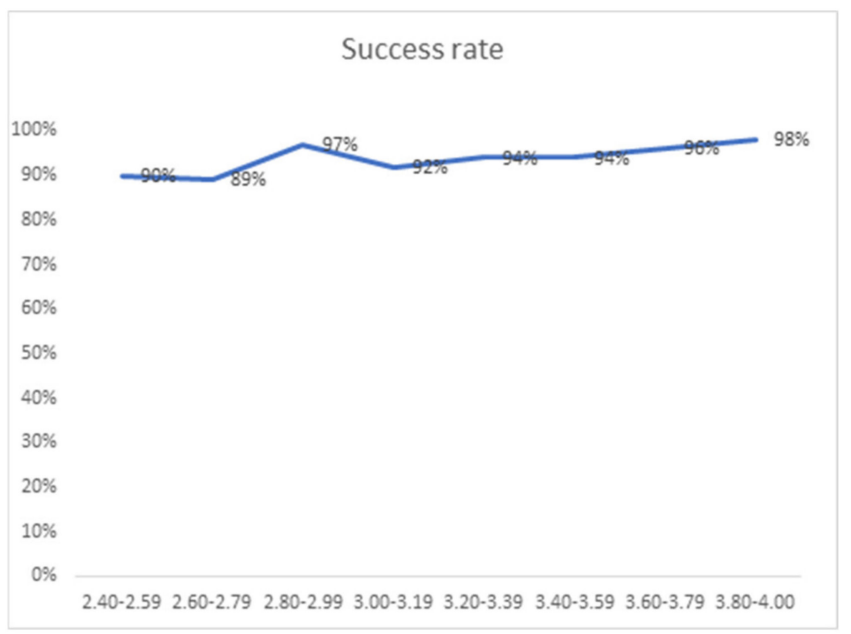

Figure 3. Undergraduate grade-point average (GPA). Percent of successful progression to Year 2. This figure illustrates that Percentage of students admitted in 2016 who progressed to Year 2 on time, by their undergraduate GPA range.

\section{Discussion}

In the context of medical education, the Grutter [21] principle of explicitly considering societal interests is particularly potent. Except for women, no minority or underserved group has improved its share of medical school matriculants in the past few decades. Medical schools continue to weigh cognitive achievement as the principal factor for selecting students, assuming that continued academic achievement over known minimal thresholds will ensure better medical practice performance; however, it is now known that above a minimum threshold academic performance is not a determinant. Applying the principles laid out in Grutter to medical school admissions may improve the representation of diverse student groups in US medical schools.

By contrast, the flaws in the current model of academic linearity have been increasingly in evidence. Educational attainment is highly correlated with household income [90]. Neighborhood quality exerts significant negative impact on the undergraduate academic performance of minorities [91]. Similarly, household income demonstrates a significant positive association with MCAT scores [92]. These ecological effects rationalize a number of points. First, they offer a complimentary alternative for the potential role of implicit bias and resentment in admissions [93,94]. Non-Hispanic white women, who demonstrated the greatest gains in representation, are also the group most socio-economically similar to the non-Hispanic white males that previously represented the majority of all applicants. Second, they suggest that even weighing cognitive factors is not a pure measure of intellectual potential but is influenced by social inequities. Finally, they affirm Flexner's observation about the need for social reform. Stark racial and economic disparities are evident in school quality, access to healthcare, and neighborhood violence. The failure of public policy to robustly redress these inequities may be postulated to make significant contributions to observed gaps in previous academic performance [95].

Given these challenges, it is significant that this work, like previous literature, suggests the efficacy of alternative pathways. Paralleling our own analysis, Terregino et al. report that medical schools that take a higher proportion of candidates from the middle third of MCAT scores report more diverse student bodies, but not meaningfully higher rates of medical school non-completion [80]. A systematic review on the determinants of medical school performance found that prior academic performance explained only $23 \%$ of the total variance [96]. Earlier still, a 20-year analysis of outcomes at the University of California Davis, the site of the infamous Bakke case, found no difference in rates of academic difficulty, graduation or licensing between students admitted through standard versus affirmative action pathways [82]. Though using higher cut-offs than recommended here, the long-term experience at Australia's University of Newcastle Medical School further chips at the myth of linearity given the outcomes for candidates selected on academic versus non-cognitive criteria [97]. While the 
cumulative weight of this evidence argues in favor of an Acceptable Threshold, the Grutter principles offer a rubric for further reconceptualizing admissions practices.

Several societal interests are implicated in the Grutter decision. Medical school matriculation determines the supply of physicians who care for the nation. The "myth of accountability", premised on the idea that internal scientific integrity equates with societal responsibility, has long been operative [98] and has led to the erosion of medicine's social contract with the public [99]. Further, some have complained that the scientific mission of academic medicine has crowded out its social responsibility to train physicians for society's most basic healthcare delivery needs [100]. The quality and availability of healthcare vary geographically, racially, by immigration status and according to the income of the recipient [101-103]. There is a compelling national and state interest in creating physicians who are willing and able to serve all Americans [19,104]. Given that minority and underprivileged matriculants have a greater likelihood of working in medically underserved communities, applying the principles of Grutter to medical school admissions may increase the supply of physicians who will care for underserved communities.

Second, the societal interests espoused by Grutter [21] are Supreme Court-validated. Professional school admissions decisions cannot be made in isolation from the population groups that will ultimately be served by the matriculant [21]. In our heterogeneous, culturally pluralistic society, citizens must have confidence that the physician supply will ultimately serve all of society and not just the wealthy or well-connected [21]. A physician's patients may come from any community in the nation [105]. Medical schools must produce not just highly competent professionals, but professionals who are willing, work-ready and fit-for-purpose. Thus, they must be optimally suited to respond to the needs of all populations including the most vulnerable [106-108] and demonstrate a positive effect upon the communities they serve [106,109]. Also present is a societal interest in preserving and expanding the opportunity for the upward mobility of medical students of all races, ethnicities and economic backgrounds [19].

The cost of education is the primary reason that high-achieving children from underrepresented minority groups and students from lower-income families choose not to pursue a college degree [110] or medical school [111]. Medical students collectively experience debt as a major stressor [112-115], but the impact is disproportionately greater on underrepresented minority students and students from lower-income families $[116,117]$. Since the cost of medical education is far greater than the tuition medical students pay, they owe a significant debt to society to participate in socially responsible activities that contribute to the happiness, health, and prosperity of less fortunate citizens [118]. Students from the socioeconomic elite still display a significant sense of entitlement and lack of social responsibility despite their low debt [113]. Formal instruction in healthcare advocacy directed at the individual, community, and legislative levels holds the most promise for addressing entitlement and fulfillment of professional standards [119].

The third societal interest relates to individual justice. Traditionally, medical school admissions have been premised on the concept of academic linearity: the candidate with the higher GPA and/or MCAT score is better qualified, and, hence, more meritorious. Given that students above a minimal threshold graduate become practicing doctors at equal rates, this is an outdated means of assessing medical school candidates for admission. Moreover, the weak or absent linkage between premedical GPAs and MCAT scores and the quality of subsequent practice beyond training makes such thinking without merit. A holistic approach that incorporates race, ethnicity, economic background and other non-cognitive factors once minimum academic achievement criteria are met allows the medical student body to better reflect the national population and potentially improve disparities in the percentage of minority and disadvantaged students in US medical schools.

Grutter [19] demonstrates that the country has a substantial and legitimate stake in every medical school admission decision. By accepting benefits from society, medical schools and students enter into an implicit contract to work with the larger society for the public good. That obligation is best carried out by educating students "in a manner that instills appropriate professional attitudes, values, 
and skills" [120]. Admission decisions should convey the institution's sense of the community it serves, especially toward the underserved and marginalized. Currently, the admissions process is skewed towards favoring academic performance and not to the community in which physicians will ultimately serve or to society $[8,121]$. Each school's selection process yields a different assortment of students [122] suggesting that schools, not society, are interpreting and therefore determining societal needs. It is difficult to reconcile the failure of medicine to address health disparities or the inability of current graduates to care for up to half of the population with successful stewardship.

Achieving more representative student bodies and doctors who will care for all segments of society occurs via actions taken by the medical schools and the graduates they produce. Despite the nearly ubiquitous diversity statement in medical school mission, vision and value statements, little progress has been made in reducing the disparities in medical school admissions. Seventy-five percent of medical schools have a specific goal for diversity [123]. Diversity policies and strategic plans are meant to guide institutional decision-making. Yet, the presence of a strategic plan to increase diversity is not associated with greater racial/ethnic faculty diversity [123]. Rarely do diversity statements make institutions fairer [124] or more inclusive. US medical schools produce heterogeneous and unequal learning environments [125-127] that fail at all three diversity paradigms: discrimination and fairness, access and legitimacy, and learning and effectiveness [128]. Each point reflects a trust deficit for DEI policies.

A medical school's mission and its outcomes should both reflect the community that it serves and vindicate the Grutter decision. Unfortunately, medical schools' strategic plans most often do little more than project supposed commitment while failing to achieve tangible results [123]. This institutional hypocrisy likely negatively impacts students' and faculty's sense of social responsibility [129]. The goal of medical school is to prepare future physicians to be responsive to the needs of patients and society and who will service all Americans $[101,130]$. Attempts to implement more inclusive admission plans have seen resistance from admissions committees concerned with litigation and academic standards [131].

If medical schools are to sustain democratic ideals and achieve health equity, they should adopt an Acceptable Threshold for academic achievement and use non-cognitive factors for admission-each school would thereby increase the participation of diverse populations, widening participation [132,133]. The Grutter legitimacy principles are succinct trust-building arguments for such shifts [21]. Both the physicians trained for and the care delivered to the communities they serve are the product of medical schools, which thus become a critical piece of medical education's obligation to the public. Admissions must be "visibly open", inclusive and intolerant of historical inequities as they advance the goals of democracy by training "talented [cultures] and qualified individuals from every race and diversity" to become physicians [21].

\section{Conclusions}

The United Nations Sustainable Development Goals aim for a radical realization of health equity at both the national and international level [134]. In outlining implementation, the Lancet Global Health Commission wisely cites public confidence as a key metric [135]. For both the implications of societal fairness and the demonstrated practice patterns of matriculants, this implies serious changes in class composition. Efforts to fulfill the vision of legitimacy principles as detailed in the Grutter decision [21] have fallen short. Apart from female matriculation, American medical schools look very similar to those in 2003 concerning the diversity of their matriculants. These failures mirror the struggle of many nations to widen the participation of their particular marginalized groups in medicine. Success will require not only narrow arguments favoring diversity but a broad-based debunking of academic linearity with its replacement by a robust principled framework that inspires confidence in the admissions process and its clarified goals. The precedent set by the legitimacy principles in the Grutter decision [21] gives us guidelines for instituting these changes in medical school admissions that seek to make matriculants better reflect the communities in which they will practice medicine. 
Author Contributions: Conceptualization, A.B. and R.F.B.; methodology, A.B. and R.F.B.; formal analysis, A.B. and R.F.B.; writing-original draft preparation, A.B. and R.F.B.; writing-review and editing, A.B. and R.F.B.; supervision, R.F.B.; project administration, R.F.B. All authors have read and agreed to the published version of the manuscript.

Funding: This research received no external funding.

Acknowledgments: We would like to thank BCB and MS for their comments on earlier versions. We are grateful to RMB and JCB for their legal review and DBW and RL for their construction of Figures 2 and 3.

Conflicts of Interest: The authors declare no conflict of interest.

Limitations: The authors readily acknowledge the limitations of nationally-available, self-reported data. Diversity, diverse identities, and critical mass are inherently institution-specific, and the meanings and context derived from the goals a school establishes for itself. No attempt was made to directly assess these concepts for any individual medical school. Rather, the assessment was made using national self-reported, publicly available data. We readily acknowledge this weakness in our analysis; however, we also acknowledge their widespread use by medical schools, the AAMC, and other organizations.

\section{References}

1. Apampa, A.; Kubacki, A.; Ojha, U.; Xiang, J. Challenges in widening participation outreach: Is enough being done to tackle the under-representation of low-income students in medicine? Adv. Med. Educ. Pract. 2019, 10, 917-923. [CrossRef] [PubMed]

2. Johnson, D.G.; Hutchins, E.B. Doctor or dropout? A study of medical student attrition. J. Med. Educ. 1966, 41, 1099-1274. [CrossRef]

3. Gliatto, P.; Leitman, I.M.; Muller, D. Scylla and Charybdis: The MCAT, USMLE, and degrees of freedom in undergraduate medical education. Acad. Med. 2016, 91, 1498-1500. [CrossRef] [PubMed]

4. Flexner, A. Medical Education in the United States and Canada; Science and Health Publications, Inc.: Washington, DC, USA, 1910.

5. Gurin, P. The compelling need for diversity in education. MIJRL 1999, 5, 363-425.

6. Gibbes, E. Whose university place is it anyway? Guardian, 9 March 2003. Available online: https: //www.theguardian.com/politics/2003/mar/09/uk.highereducation (accessed on 29 May 2020).

7. British Broadcasting Corporation (BBC). ‘University bias' debate rumbles on. BBC News, 3 March 2003. Available online: http://news.bbc.co.uk/2/hi/uk_news/education/2814743.stm (accessed on 29 May 2020).

8. Razack, S.; Maguire, M.; Hodges, B.; Steinert, Y. What might we be saying to potential applicants to medical school? Discourses of excellence, equity, and diversity on the Web sites of Canada's 17 medical schools. Acad. Med. 2012, 87, 1323-1329. [CrossRef]

9. Hanson, M.; Moineau, G.; Kulasegaram, K.; Hammond, R. Is Canada ready for nationwide collaboration on medical school admissions practices and policies? Acad. Med. 2016, 91, 1501-1508. [CrossRef]

10. Stegers-Jaeger, K.; Steyerberg, E.; Lucieer, S.; Themmen, A. Ethnic and social disparities in performance on medical school selection criteria. Med. Educ. 2015, 49, 124-133. [CrossRef] [PubMed]

11. Izawa, T.; Juntendo, U. Medical school rejected 165 women, others despite good entrance exam scores. The Mainichi, 11 December 2018. Available online: https://mainichi.jp/english/articles/20181211/p2a/00m/0na/ 002000c (accessed on 29 May 2020).

12. Easton, D. A Systems Analysis of Political Life; John Wiley \& Sons: New York, NY, USA, 1965; ISBN 139780471229407.

13. Fukuyama, F. Trust: The Social Virtues and the Creation of Prosperity; Free Press: New York, NY, USA, 1995; ISBN 139780684825250.

14. Gyorffy, D. Institutional Trust and Economic policy: Lessons from the Euro; Central European University Press: Budapest, Hungary, 2013; ISBN 139786155225222.

15. Office of the President. The Michigan Mandate: A Seven Year Progress Report 1987-1994. Available online: http://milproj.dc.umich.edu/Michigan_Mandate/pdf/Michigan\%20Mandate-Progress.pdf (accessed on 27 July 2018).

16. Roach, R. Remembering the Michigan Mandate. Diverse Issues in Higher Education, 26 August 2006. Available online: https://diverseeducation.com/article/6264/ (accessed on 22 July 2018).

17. Hafferty, F.W. Beyond curricular reform: Confronting medicine's hidden curriculum. Acad. Med. 1998, 73, 403-407. [CrossRef] 
18. Regents of University of California v. Bakke 438 U.S. 265 (1978). Available online: http://studythepast.com/ civilrightsundergraduate/cases/bakke.pdf (accessed on 7 November 2018).

19. Grutter v. Bollinger (02-241) 539 U.S. 306 (2003), p. 316. Available online: https://www.law.cornell.edu/supct/ html/02-241.ZO.html (accessed on 7 November 2018).

20. Fisher v. University of Texas at Austin, 579 U.S. (2016). Available online: https://supreme.justia.com/cases/ federal/us/579/14-981/ (accessed on 7 November 2018).

21. Grutter v. Bollinger (02-241) 539 U.S. 306 (2003), p. 333. Available online: https://www.law.cornell.edu/supct/ html/02-241.ZO.html (accessed on 7 November 2018).

22. Oyez. Grutter v. Bollinger. Available online: https://www.oyez.org/cases/2002/02-241 (accessed on 15 October 2017).

23. Lee, P. On checkbox diversity. J. Civil Rights Econ. Dev. 2013, 27, 203-216. Available online: https: //Ssrn.Com/Abstract=2413049 (accessed on 11 April 2018).

24. Ferguson, E.; Lievens, F. Future directions in personality, occupational and medical selection: Myths, misunderstandings, measurement, and suggestions. Adv. Health Sci. Educ. Theory Pract. 2017, 22, 387-399. [CrossRef]

25. Frost, H.; Regehr, G. "I am a doctor": Negotiating the discourses of standardization and diversity in professional identity construction. Acad. Med. 2013, 88, 1570-1577. [CrossRef] [PubMed]

26. Phillips, K.W.; Rothbard, N.P.; Dumas, T.L. To Disclose or not to disclose? Status distance and self-disclosure in diverse environments. Acad. Manag. Rev. 2009, 34, 710-732. [CrossRef]

27. Hardeman, R.R.; Przedworski, J.M.; Burke, S.; Burgess, D.J.; Perry, S.; Phelan, S.; Dovidio, J.F.; van Ryn, M. Association between perceived medical school diversity climate and change in depressive symptoms among medical students: A report from the medical student CHANGE study. J. Natl. Med. Assoc. 2016, 108, 225-235. [CrossRef]

28. Bowman, N.A. How much diversity is enough? The curvilinear relationship between college diversity interactions and first-year student outcomes. Res. High. Educ. 2013, 54, 874-894. [CrossRef]

29. Association of American Medical Colleges. Holistic Review in Medical School Admissions. Available online: https://students-residents.aamc.org/choosing-medical-career/article/holistic-reviewmedical-school-admissions (accessed on 27 March 2017).

30. Witzburg, R.A.; Sondheimer, H.M. Holistic review-shaping the medical profession one applicant at a time. N. Engl. J. Med. 2013, 368, 1565-1567. [CrossRef]

31. Eva, K.W.; Rosenfeld, J.; Reiter, H.I.; Norman, G.R. An admissions OSCE: The multiple mini-interview. Med. Educ. 2004, 38, 314-326. [CrossRef] [PubMed]

32. Committee, A. Behavioral and Social Science Foundations for Future Physicians; Association of American Medical Colleges: Washington, DC, USA, 2011.

33. Institute A.M.C.H.A.M. Scientific Foundations for Future, Physicians; Institute, A.M.C.H.A.M.: Washington, DC, USA, 2009.

34. Proctor, B.D.; Semega, J.L.; Kollar, M.A. Income and poverty in the United States: 2015. In Current Population Reports; US Census Bureau: Washington, DC, USA, 2016; pp. 60-256.

35. Fontenot, K.; Semega, J.; Kollar, M. Income and Poverty in the United States: 2017. In Current Population Reports; US Census Bureau: Washington, DC, USA, 2018; pp. 60-263.

36. Dunleavy, D.; Sondheimer, H.; Castillo-Page, L.; Bletzinger, R. Medical school admissions: More than grades and test scores. AAMC Anal. Brief. 2011,11,1-2.

37. Monroe, A.; Quinn, E.; Samuelson, W.; Dunleavy, D.M.; Dowd, K.W. An overview of the medical school admission process and use of applicant data in decision making: What has changed since the 1980s? Acad. Med. 2013, 88, 672-681. [CrossRef] [PubMed]

38. Association of American Medical Colleges. Graduation Rates and Attrition Rates of U.S. Medical Students. Available online: https://www.aamc.org/download/492842/data/graduationratesandattritionratesofu.s. medicalstudents.pdf (accessed on 23 January 2019).

39. Association of American Medical Colleges. Number of Medical Schools Requiring the United States Medical Licensing Examination. (USMLE) for Graduation. Available online: https:/www.aamc.org/initiatives/cir/ 406442/10b.html (accessed on 29 December 2018).

40. Lett, L.A.; Murdock, H.M.; Orji, W.U.; Aysola, J.; Sebro, R. Trends in racial/ethnic representation among US medical students. JAMA Netw. Open 2019, 2, e1910490. [CrossRef] 
41. Musu-Gillette, L.; De Brey, C.; McFarland, J.; Hussar, W.; Sonnenberg, W.; Wilkinson-Flicker, S. Status and trends in the education of racial and ethnic groups 2017. NCES 2017-051. Natl. Cent Educ. Stat. 2017.

42. Laurencin, C.T.; Murray, M. An American crisis: The lack of black men in medicine. J. Racial Ethn. Health Disparities 2017, 4, 317-321. [CrossRef]

43. U.S. Department of Education, N.C.E.S. Number of STEM Degrees/Certificates Conferred to U.S. Citizens and Nonresident Aliens. Table 318.45. Number and Percentage Distribution of Science, Technology, Engineering, and Mathematics (STEM) Degrees/Certificates Conferred by Postsecondary Institutions, by Race/Ethnicity, Level of Degree/Certificate, and Sex of Student: 2008-09 through 2015-16. Available online: https://nces.ed.gov/programs/digest/d16/tables/dt16_318.45.asp (accessed on 11 March 2018).

44. Youngclaus, J.; Roskovensky, L. An updated look at the economic diversity of US medical students. AAMC Anal. Brief. 2018, 18, 1-3.

45. Cantor, J.C.; Miles, E.L.; Baker, L.C.; Barker, D.C. Physician service to the underserved: Implications for affirmative action in medical education. Inquiry 1996, 33, 167-180. [PubMed]

46. Isaac, J.; Davis, K.; Fike, R.; Isaac, P.; Archer, A.; Aroh, C.; Ume, A. An idea whose time has come: The need for increased diversity in medical practice and education. West. J. Black Stud. 2014, 38, 35.

47. Komaromy, M.; Grumbach, K.; Drake, M.; Vranizan, K.; Lurie, N.; Keane, D.; Bindman, A.B. The role of black and Hispanic physicians in providing health care for underserved populations. N. Engl. J. Med. 1996, 334, 1305-1310. [CrossRef] [PubMed]

48. Puddey, I.B.; Playford, D.E.; Mercer, A. Impact of medical student origins on the likelihood of ultimately practicing in areas of low vs high socio-economic status. BMC Med. Educ. 2017, 17, 1. [CrossRef] [PubMed]

49. Rabinowitz, H.K.; Diamond, J.J.; Veloski, J.J.; Gayle, J.A. The impact of multiple predictors on generalist physicians' care of underserved populations. Am. J. Public Health 2000, 90, 1225-1228. [CrossRef]

50. Dietz, T.; Kalof, L.; Stern, P. Gender, values, and environmentalism. Soc. Sci. Q. 2002, 83, 353-364. [CrossRef]

51. Suizzo, M.-A. Parents' goals and values for children: Dimensions of independence and interdependence across four US ethnic groups. J. Cross-Cult. Psychol. 2007, 38, 506-530. [CrossRef]

52. Bell, M.P.; Harrison, D.A. Using intra-national diversity for international assignments: A model of bicultural competence and expatriate adjustment. Hum. Resour. Manag. Rev. 1996, 6, 47-74. [CrossRef]

53. Oyserman, D. Culture as situated cognition: Cultural mindsets, cultural fluency, and meaning making. Eur. Rev. Soc. Psychol. 2011, 22, 164-214. [CrossRef]

54. Piff, P.K.; Stancato, D.M.; Martinez, A.G.; Kraus, M.W.; Keltner, D. Class, chaos, and the construction of community. J. Pers. Soc. Psychol. 2012, 103, 949-962. [CrossRef] [PubMed]

55. Longest, K.C.; Hitlin, S.; Vaisey, S. Position and disposition: The contextual development of human values. Soc. Forces 2013, 91, 1499-1528. [CrossRef]

56. Stephens, N.M.; Markus, H.R.; Phillips, L.T. Social class culture cycles: How three gateway contexts shape selves and fuel inequality. Annu. Rev. Psychol. 2014, 65, 611-634. [CrossRef]

57. Martin, S.R.; Côté, S. Social class transitioners: Their cultural abilities and organizational importance. Acad. Manag. Rev. 2019, 44, 618-642. [CrossRef]

58. Piff, P.K.; Robinson, A.R. Social class and prosocial behavior: Current evidence, caveats, and questions. Curr. Opin. Psychol. 2017, 18, 6-10. [CrossRef]

59. Van Ryn, M.; Fu, S.S. Paved with good intentions: Do public health and human service providers contribute to racial/ethnic disparities in health? Am. J. Public Health 2003, 93, 248-255. [CrossRef] [PubMed]

60. Marrast, L.M.; Zallman, L.; Woolhandler, S.; Bor, D.H.; McCormick, D. Minority physicians' role in the care of underserved patients: Diversifying the physician workforce may be key in addressing health disparities. JAMA Intern. Med. 2014, 174, 289-291. [CrossRef]

61. Association of American Medical Colleges. Current trends in Medical Education 2016. Available online: http://www.aamcdiversityfactsandfigures2016.org/report-section/section-3/\#figure-28 (accessed on 4 September 2018).

62. Mitchell, D.A.; Lassiter, S.L. Addressing health care disparities and increasing workforce diversity: The next step for the dental, medical, and public health professions. Am. J. Public Health 2006, 96, 2093-2097. [CrossRef] [PubMed]

63. Walker, K.O.; Moreno, G.; Grumbach, K. The association among specialty, race, ethnicity, and practice location among California physicians in diverse specialties. J. Natl. Med. Assoc. 2012, 104, 46-52. [CrossRef] 
64. Wayne, S.J.; Kalishman, S.; Jerabek, R.N.; Timm, C.; Cosgrove, E. Early predictors of physicians' practice in medically underserved communities: A 12-year follow-up study of University of New Mexico School of Medicine graduates. Acad. Med. 2010, 85, S13-S16. [CrossRef]

65. Association of American Medical Colleges. 2017 Applicant and Matriculant Data Tables. Available online: https://aamc-black.global.ssl.fastly.net/production/media/filer_public/5c/26/5c262575-52f94608-96d6-a78cdaa4b203/2017_applicant_and_matriculant_data_tables.pdf (accessed on 20 September 2018).

66. Cislak, A.; Formanowicz, M.; Saguy, T. Bias against research on gender bias. Scientometrics 2018, 115, $189-200$. [CrossRef]

67. Greenwood, B.N.; Carnahan, S.; Huang, L. Patient-physician gender concordance and increased mortality among female heart attack patients. Proc. Natl. Acad. Sci. USA 2018, 115, 8569-8574. [CrossRef] [PubMed]

68. Wallis, C.J.; Ravi, B.; Coburn, N.; Nam, R.K.; Detsky, A.S.; Satkunasivam, R. Comparison of postoperative outcomes among patients treated by male and female surgeons: A population based matched cohort study. BMJ 2017, 359, j4366. [CrossRef] [PubMed]

69. Butkus, R.; Serchen, J.; Moyer, D.V.; Bornstein, S.S.; Hingle, S.T.; for the Health and Public Policy Committee of the American College of Physicans. Achieving gender equity in physician compensation and career advancement: A position paper of the American college of physicians. Ann. Intern. Med. 2018, 168, 721-723. [CrossRef] [PubMed]

70. Carr, P.L.; Gunn, C.; Raj, A.; Kaplan, S.; Freund, K.M. Recruitment, promotion, and retention of women in academic medicine: How institutions are addressing gender disparities. Womens Health Issues 2017, 27, 374-381. [CrossRef]

71. Carr, P.L.; Raj, A.; Kaplan, S.E.; Terrin, N.; Breeze, J.L.; Freund, K.M. Gender differences in academic medicine: Retention, rank, and leadership comparisons from the national faculty survey. Acad. Med. 2018, 93, 1694-1699. [CrossRef]

72. Carnes, M.; Devine, P.G.; Baier Manwell, L.; Byars-Winston, A.; Fine, E.; Ford, C.E.; Forscher, P.; Isaac, C.; Kaatz, A.; Magua, W.; et al. The effect of an intervention to break the gender bias habit for faculty at one institution: A cluster randomized, controlled trial. Acad. Med. 2015, 90, 221-230. [CrossRef]

73. Devine, P.G.; Forscher, P.S.; Cox, W.T.L.; Kaatz, A.; Sheridan, J.; Carnes, M. A gender bias habit-breaking intervention led to increased hiring of female faculty in STEMM departments. J. Exp. Soc. Psychol. 2017, 73, 211-215. [CrossRef]

74. Raj, A.; Kumra, T.; Darmstadt, G.L.; Freund, K.M. Achieving gender and social equality: More than gender parity is needed. Acad. Med. 2019, 94, 1658-1664. [CrossRef] [PubMed]

75. Association of American Medical Colleges. The New Score Scales for the 2015 MCAT Exam: An Overview of What Admissions Officers Need to Know. Available online: https://aamc-orange.global.ssl.fastly.net/ production/media/filer_public/0a/ec/0aec7917-adf3-406a-b304-e97922860332/mcat2015scorescaleguide.pdf (accessed on 2 February 2018).

76. Dunleavy, D.M.; Kroopnick, M.H.; Dowd, K.W.; Searcy, C.A.; Zhao, X. The predictive validity of the MCAT exam in relation to academic performance through medical school: A national cohort study of 2001-2004 matriculants. Acad. Med. 2013, 88, 666-671. [CrossRef] [PubMed]

77. Huff, K.L.; Fang, D. When are students most at risk of encountering academic difficulty? A study of the 1992 matriculants to U.S. medical schools. Acad. Med. 1999, 74, 454-460. [CrossRef] [PubMed]

78. Association of American Medical Colleges. Using MCAT Data in Medical Student Selection. Available online: https://www.aamc.org/system/files/c/2/462316-mcatguide.pdf (accessed on 19 March 2020).

79. Grbic, D.; Jones, D.J.; Case, S.T. The role of socioeconomic status in medical school admissions: Validation of a socioeconomic indicator for use in medical school admissions. Acad. Med. 2015, 90, 953-960. [CrossRef] [PubMed]

80. Terregino, C.A.; Saguil, A.; Price-Johnson, T.; Anachebe, N.F.; Goodell, K. The diversity and success of medical school applicants with scores in the middle third of the MCAT score scale. Acad. Med. 2020, 95, 344-350. [CrossRef]

81. Julian, E.R. Validity of the Medical College Admission Test for predicting medical school performance. Acad. Med. 2005, 80, 910-917. [CrossRef]

82. Davidson, R.C.; Lewis, E.L. Affirmative action and other special consideration admissions at the University of California, Davis, School of Medicine. JAMA 1997, 278, 1153-1158. [CrossRef] 
83. Saguil, A.; Dong, T.; Gingerich, R.J.; Swygert, K.; LaRochelle, J.S.; Artino, A.R., Jr.; Cruess, D.F.; Durning, S.J. Does the MCAT predict medical school and PGY-1 performance? Mil. Med. 2015, 180, 4-11. [CrossRef]

84. Bills, J.L.; Van Houten, J.; Grundy, M.M.; Chalkley, R.; Dermody, T.S. Validity of the Medical College Admission Test for predicting MD-PhD student outcomes. Adv. Health Sci. Educ. 2016, 21, 33-49. [CrossRef]

85. Das, J.; Hammer, J. Money for nothing: The dire straits of medical practice in Delhi, India. J. Dev. Econ. 2007, 83, 1-36. [CrossRef]

86. Leonard, K.L.; Masatu, M.C. Professionalism and the know-do gap: Exploring intrinsic motivation among health workers in Tanzania. Health Econ. 2010, 19, 1461-1477. [CrossRef]

87. Rethans, J.J.; van Leeuwen, Y.; Drop, R.; van der Vleuten, C.; Sturmans, F. Competence and performance: Two different concepts in the assessment of quality of medical care. Fam. Pract. 1990, 7, 168-174. [CrossRef] [PubMed]

88. Elks, M.L.; Herbert-Carter, J.; Smith, M.; Klement, B.; Knight, B.B.; Anachebe, N.F. Shifting the curve: Fostering academic success in a diverse student body. Acad. Med. 2018, 93, 66-70. [CrossRef] [PubMed]

89. Association of American Medical Colleges. What's on the MCAT Exam? Available online: https://studentsresidents.aamc.org/applying-medical-school/article/whats-mcat-exam/ (accessed on 12 June 2018).

90. Keller, K. How can educational policy improve income distribution? An empirical analysis of education stages and measures on income inequality. J. Dev. Areas 2010, 43, 51-77. [CrossRef]

91. Massey, D.; Fischer, J. The effect of childhood segregation on minority academic performance at selective colleges. Ethn. Racial Stud. 2006, 29, 1-26. [CrossRef]

92. Fadem, B.; Schuchman, M.; Simring, S. The relationship between parental income and academic performance of medical students. Acad. Med. 1995, 70, 1142-1144. [CrossRef]

93. Capers, Q.; Clinchot, D.; McDougle, L.; Greenwald, A. Implicit racial bias in medical school admissions. Acad. Med. 2017, 92, 365-369. [CrossRef] [PubMed]

94. Legault, L.; Gutsell, J.N.; Inzlicht, M. Ironic effects of antiprejudice messages: How motivational interventions can reduce (but also increase) prejudice. Psychol. Sci. 2011, 22, 1472-1477. [CrossRef]

95. Lucey, C.; Saguil, A. The consequences of structural racism on MCAT scores and medical school admissions: The past is prologue. Acad. Med. 2020, 95, 351-356. [CrossRef]

96. Ferguson, E.; James, D.; Madeley, L. Factors associated with success in medical school: Systematic review of the literature. BMJ 2002, 324, 952-957. [CrossRef]

97. Powis, D.; Munro, D.; Bore, M.; Burstal, A. In-course and career outcomes predicted by medical school selection procedures based on personal qualities. Med. Teach. 2020, 16, 1-3. [CrossRef]

98. Bruhn, J.G. On social responsibility. J. Med. Educ. 1971, 46, 166-168. [CrossRef] [PubMed]

99. Wynia, M.K. The short history and tenuous future of medical professionalism: The erosion of medicine's social contract. Perspect. Biol. Med. 2008, 51, 565-578. [CrossRef] [PubMed]

100. Bloom, S.W. The medical school as a social organization: The sources of resistance to change. Med. Educ. 1989, 23, 228-241. [CrossRef] [PubMed]

101. Taylor, J. Racism, Inequality, and Health Care for African Americans; The Century Foundation: Washington, DC, USA, December 2019.

102. Derose, K.P.; Escarce, J.J.; Lurie, N. Immigrants and health care: Sources of vulnerability. Health Aff. (Millwood) 2007, 26, 1258-1268. [CrossRef] [PubMed]

103. Foundation, R.W.J. Race, Racism and Health. An RWJF Collection. Available online: https://www.rwjf.org/ en/library/collections/racism-and-health.html (accessed on 5 January 2019).

104. DeVille, K.; Kopelman, L.M. Diversity, trust, and patient care: Affirmative action in medical education 25 years after Bakke. J. Med. Philos. 2003, 28, 489-516. [CrossRef]

105. Coulehan, J.; Williams, P.C.; McCrary, S.V.; Belling, C. The best lack all conviction: Biomedical ethics, professionalism, and social responsibility. Camb. Q. Healthc. Ethics 2003, 12, 21-38. [CrossRef]

106. Boelen, C.; Heck, J.E.; World Health Organization. Defining and Measuring the Social Accountability of Medical Schools; World Health Organization: Geneva, Switzerland, 1995.

107. Larkins, S.L.; Preston, R.; Matte, M.C.; Lindemann, I.C.; Samson, R.; Tandinco, F.D.; Buso, D.; Ross, S.J.; Palsdottir, B.; Neusy, A.J.; et al. Measuring social accountability in health professional education: Development and international pilot testing of an evaluation framework. Med. Teach. 2013, 35, 32-45. [CrossRef] 
108. Palsdottir, B.; Neusy, A.J.; Reed, G. Building the evidence base: Networking innovative socially accountable medical education programs. Educ. Health (Abingdon) 2008, 21, 177.

109. Boelen, C.; Pearson, D.; Kaufman, A.; Rourke, J.; Woollard, R.; Marsh, D.C.; Gibbs, T. Producing a socially accountable medical school: AMEE Guide No. 109. Med. Teach. 2016, 38, 1078-1091. [CrossRef]

110. Cox, D.; Lienesch, R.; Jones, R.P. Beyond Economics: Fears of Cultural Displacement Pushed the White Working Class to Trump; PRRI/The Atlantic Report: Washington, DC, USA, 2017.

111. Association, A.M.S. Medical Student Debt. Available online: https://www.amsa.org/advocacy/actioncommittees/twp/medical-student-debt/ (accessed on 17 June 2018).

112. Morra, D.J.; Regehr, G.; Ginsburg, S. Anticipated debt and financial stress in medical students. Med. Teach. 2008, 30, 313-315. [CrossRef]

113. Phillips, J.P.; Wilbanks, D.M.; Salinas, D.F.; Doberneck, D.M. Educational debt in the context of career planning: A qualitative exploration of medical student perceptions. Teach. Learn. Med. 2016, 28, $243-251$. [CrossRef]

114. Rohlfing, J.; Navarro, R.; Maniya, O.Z.; Hughes, B.D.; Rogalsky, D.K. Medical student debt and major life choices other than specialty. Med. Educ. Online 2014, 19, 25603. [CrossRef]

115. Wolf, T.M.; Faucett, J.M.; Randall, H.M.; Balson, P.M. Graduating medical students' ratings of stresses, pleasures, and coping strategies. J. Med. Educ. 1988, 63, 636-642. [CrossRef] [PubMed]

116. Dugger, R.A.; El-Sayed, A.M.; Dogra, A.; Messina, C.; Bronson, R.; Galea, S. The color of debt: Racial disparities in anticipated medical student debt in the United States. PLoS ONE 2013, 8, e74693. [CrossRef]

117. Youngclaus, J.; Fresne, J.A. Physician Education Debt and the Cost to Attend Medical School: 2012 Update; Association of American Medical Colleges: Washington, DC, USA, 2013.

118. Rein, M.F.; Randolph, W.J.; Short, J.G.; Coolidge, K.G.; Coates, M.L.; Carey, R.M. Defining the cost of educating undergraduate medical students at the University of Virginia. Acad. Med. 1997, 72, 218-227. [CrossRef] [PubMed]

119. Lax, Y.; Braganza, S.; Patel, M. Three-tiered advocacy: Using a longitudinal curriculum to teach pediatric residents advocacy on an individual, community, and legislative level. J. Med. Educ. Curric. Dev. 2019, 6. [CrossRef] [PubMed]

120. McCurdy, L.; Goode, L.D.; Inui, T.S.; Daugherty, R.M., Jr.; Wilson, D.E.; Wallace, A.G.; Weinstein, B.M.; Copeland, E.M., III. Fulfilling the social contract between medical schools and the public. Acad. Med. 1997, 72, 1063-1070. [CrossRef]

121. Cleland, J. The medical school admissions process and meeting the public's health care needs: Never the Twain shall meet? Acad. Med. 2018, 93, 972-974. [CrossRef]

122. Wilson, I.; Griffin, B.; Lampe, L.; Eley, D.; Corrigan, G.; Kelly, B.; Stagg, P. Variation in personality traits of medical students between schools of medicine. Med. Teach. 2013, 35, 944-948. [CrossRef]

123. Washington, D.M.; Paasche-Orlow, M.K.; Liebschutz, J.M. Promoting progress or propagating problems: Strategic plans and the advancement of academic faculty diversity in U.S. medical schools. J. Natl. Med. Assoc. 2017, 109, 72-78. [CrossRef] [PubMed]

124. Dover, T.L.; Major, B.; Kaiser, C.R. Diversity policies rarely make companies fairer, and they feel threatening to white men. Harv. Bus. Rev. 2016, 4.

125. Jenkins, T.M. Dual autonomies, divergent approaches: How stratification in medical education shapes approaches to patient care. J. Health Soc. Behav. 2018, 59, 268-282. [CrossRef] [PubMed]

126. Kellogg, K.C. Challenging Operations: Medical Reform and Resistance in Surgery; University of Chicago Press: Chicago, IL, USA, 2011.

127. Underman, K.; Hirshfield, L.E. Detached concern?: Emotional socialization in twenty-first century medical education. Soc. Sci. Med. 2016, 160, 94-101. [CrossRef] [PubMed]

128. Kwon, C.-K.; Nicolaides, A. Managing diversity through triple-loop learning. Hum. Resour. Dev. Rev. 2017, 16, 85-99. [CrossRef]

129. Babu, N.; De Roeck, K.; Raineri, N. Hypocritical organizations: Implications for employee social responsibility. J. Bus. Res. 2019. [CrossRef]

130. Association of American Medical Colleges. Brief of the Association of American Medical Colleges 2015. As Amici Curiae in Support of Respondents in Fisher v. University of Texas at Austin, et al., U.S. Supreme Court, No. 14-981. Available online: https://www.aamc.org/download/447744/data/ aamcfilesamicusbriefinfishervutaustin.pdf (accessed on 14 August 2018). 
131. Price-Johnson, T.N. The cinderella syndrome: A case study of medical school admission decisions. Ph.D. Thesis, The University of Arizona, Tucson, AZ, USA, 2013.

132. Cohen, J.J.; Gabriel, B.A.; Terrell, C. The case for diversity in the health care workforce. Health Aff. (Millwood) 2002, 21, 90-102. [CrossRef]

133. Jackson, C.S.; Gracia, J.N. Addressing health and health-care disparities: The role of a diverse workforce and the social determinants of health. Public Health Rep. 2014, 129 (Suppl. S2), 57-61. [CrossRef]

134. UN Sustainable Development Goals: Health. Available online: https://www.un.org/sustainabledevelopment/ health/ (accessed on 29 May 2020).

135. Kruk, M.E.; Gage, A.D.; Arsenault, C.; Jordan, K.; Leslie, H.H.; Roder-DeWan, S.; Adeyi, O.; Barker, P.; Daelmans, B.; Doubova, S.V. High-quality health systems in the Sustainable Development Goals era: Time for a revolution. Lancet 2018, 18, e1196-e1252. [CrossRef]

(C) 2020 by the authors. Licensee MDPI, Basel, Switzerland. This article is an open access article distributed under the terms and conditions of the Creative Commons Attribution (CC BY) license (http://creativecommons.org/licenses/by/4.0/). 